\title{
ASO Author Reflections: Modified External Oblique Myocutaneous Flap for Breast Cancer
}

\author{
René Aloisio da Costa Vieira, $\mathrm{MD}, \mathrm{PhD}^{1,2}$, Idam de Oliveira-Junior, $\mathrm{MD}, \mathrm{PhD}^{2,3}$, Luciano Ipólito Branquinho, $\mathrm{MD}^{3}$, \\ Raphael Luiz Haikel, $\mathrm{MD}^{3}$, and $\mathrm{An}$ Wan Ching, $\mathrm{MD}, \mathrm{PhD}^{4}$
}

${ }^{1}$ Programa de Pós-Graduação em Oncologia, Hospital de Cancer de Barretos, Barretos, Brazil; ${ }^{2}$ Programa de PósGraduação em Tocoginecologia, Faculdade de Medicina de Botucatu, Universidade Estadual Paulista Júlio de Mesquita Filho - UNESP, São Paulo, Brazil; ${ }^{3}$ Departamento de Mastologia e Reconstrução Mamária, Hospital de Câncer de Barretos, Barretos, Brazil; ${ }^{4}$ Departamento de Cirurgia Plástica, Universidade Federal de Sao Paulo, Escola Paulista de Medicina - UNIFESP, São Paulo, Brazil

\section{PAST}

Locally advanced breast tumors (LABT) at the limit of resectability are a problem in clinical practice. Fasciocutaneous flaps or myocutaneous flaps allow skin coverage after cutaneous extended resections, and the latissimus dorsi flap is the most common option used. ${ }^{1,2}$

\section{PRESENT}

New therapies are able to decrease the size of LABTs, ${ }^{3}$ but some tumors are poor responders, making extended surgery necessary for local control. ${ }^{1,2}$ The external oblique myocutaneous flap is an option after LABT resection, with acceptable rates of complications. ${ }^{4}$

\section{FUTURE}

The modified external oblique myocutaneous flap is another possible option after LABT resection, and allows resection of large tumors at the limit of resectability. ${ }^{5}$

\section{REFERENCES}

1. Deo SV, Purkayastha J, Shukla NK, Asthana S. Myocutaneous versus thoraco-abdominal flap cover for soft tissue defects following surgery for locally advanced and recurrent breast cancer. J Surg Oncol. 2003;83(1):31-5.

2. Vieira R, da Silva KMT, de Oliveira-Junior I, de Lima MA. ITADE flap after mastectomy for locally advanced breast cancer: a good choice for mid-sized defects of the chest wall, based on a systematic review of thoracoabdominal flaps. J Surg Oncol. 2017;115(8):949-58.

3. Pathak M, Dwivedi SN, Deo SVS, Thakur B, Sreenivas V, Rath GK. Neoadjuvant chemotherapy regimens in treatment of breast cancer: a systematic review and network meta-analysis protocol. Syst. Rev. 2018;7(1):89.

4. Lee S, Jung Y, Bae Y. Immediate chest wall reconstruction using an external oblique myocutaneous flap for large skin defects after mastectomy in advanced or recurrent breast cancer patients: a single center experience. J Surg Oncol. 2018;117(2):124-9.

5. Vieira RAC, Oliveira-Junior I, Branquinho LI, Haikel RL, Ching AW. Modified external oblique myocutaneous flap for repair of postmastectomy defects in locally advanced breast tumors. A cohort series associated with a systematic review of literature. Ann Surg Oncol. 2020. https://doi.org/10.1245/s10434-020-09205-y.

Publisher's Note Springer Nature remains neutral with regard to jurisdictional claims in published maps and institutional affiliations.

(C) Society of Surgical Oncology 2020

First Received: 29 September 2020

Accepted: 4 October 2020;

Published Online: 30 October 2020

R. A. da Costa Vieira, MD, PhD

e-mail: reneacv@gmail.com 